San Jose State University

SJSU ScholarWorks

Faculty Publications

Geology

$1-1-1990$

\title{
Lottery Proceeds in California Pay for Installation of a Ground- Water Monitoring System
}

June Ann Oberdorfer

San Jose State University, june.oberdorfer@sjsu.edu

J. W. Williams

M. G. Smelser

Follow this and additional works at: https://scholarworks.sjsu.edu/geol_pub

Part of the Geology Commons

\section{Recommended Citation}

June Ann Oberdorfer, J. W. Williams, and M. G. Smelser. "Lottery Proceeds in California Pay for Installation of a Ground-Water Monitoring System" Journal of Geological Education (1990): 13-15.

This Article is brought to you for free and open access by the Geology at SJSU ScholarWorks. It has been accepted for inclusion in Faculty Publications by an authorized administrator of SJSU ScholarWorks. For more information, please contact scholarworks@sjsu.edu. 


\section{Lottery Proceeds in California Pay for Installation of a Ground-Water Monitoring System}

June Ann Oberdorfer, John Wharton Williams, and Mark Gordon Smelser

Department of Geology

San Jose State University

San Jose, CA 95192-0102

\begin{abstract}
The installation of three water welis on the San Jose State University campus permits graduate and undergradwate students to gain field and laboratory experience in conducting many hydrogeological tests such as water sampling, pump, siug and bail tests, and aquifer definition. Installation was made possible with funds from the State of California Lottery and cooperative arrangements with a local consulting-geology firm. Many potential employers have noted that these opportunities to gain field experience will enhance the students' employment opportunities.

Key words: Appartus; field geology; hydrogeology and hydrology; engineering and environmental geology; geology teaching; geology - public affairs.
\end{abstract}

Students in the Department of Geology at San Jose State University have the opportunity to benefit from funds generated by the California State Lottery. Approximately one-third of every dollar spent on the state lottery is used to help education. The Department of Geology received lottery funds in 1988 , and used them to develop a unique environment for teaching hydrogeology. Immediately adjacent to the Duncan Hall of Science, in which the Geology Department is housed, three wells were installed, one 4-inch and two 2 -inch, approximately 75 feet dee; (see Figure 1). The location of the wells was chosen to make it convenient for students to conduct pump and slug-and-bail tests and to collect water for various water-quality analyses. Through cost-sharing arrangements with a geological-consutting firm in San Jose, EMCON, the total cost of drilling, logging, casing, and developing the wells was approximately $\$ 7,000$. EMCON has employed many Department of Geology graduates and also frequently hires geology students on a part-lime basis. The 4-inch well is the pumping well and the two 2-inch wells serve as monitoring wells. A pump is being installed so that students can collect their own data characterizing the penetrated aquifer. Padon-monitoring equipment will be installed in one well casing to permit long-term gas monitoring both for toxicity studies and for evaluation as an earthquake precursor. Because of the proximity of the wells to the Geology Department, continuous records can be transmitted directly to faculty offices and ciassrooms.

Throughout the period of the well driling and development process, a videotape record was made. Staff geologists from the consulting firm and department faculty provided expanded commentary on the various procedures as they were being completed (Figure 2). The edited tape is used in engineering geology, hydrogeology, and other classes at both the introductory and advanced levels. The engineering geology and hydrogeology classes took advantage of the construction activity as a "Iive" demonstration. Many students spent hours watching the operation, thus having the opportunity to learn first hand what goes into a successful drilling program (Figure 3). In addition, students had the opportunity on occasion to see that things do not always go as planned

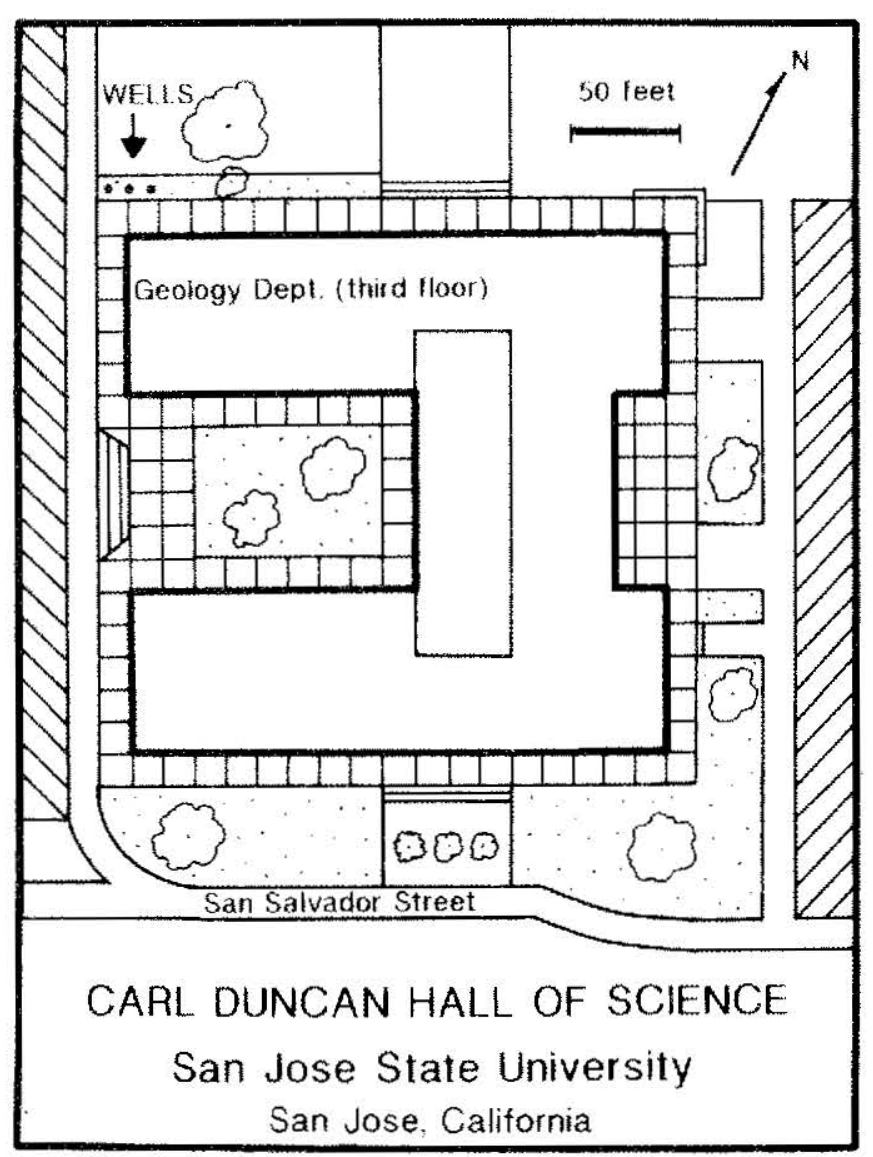

Figure 1. Location of the three wells (one pumping and two obsenation) immediately adjacent to the Duncan Hall of Science which houses the Geology Department on the San Jose State University campus.

and that in working with the subsurface environment the unexpected should be expected. The benefits of the activity are reflected in the statement of one of the Department's graduate students: "For me, it's an outstanding experience. The teachers can say many things during their lectures, but here, it's a live lecture."

Standard penetration tests were done and continuous core was recovered from one of the holes. This core was logged by the consulting firm's geologists, and the final logs were given to the Department (Figure 4). The core was placed in core boxes and given to the Department and has since been used in a number of core-logging exercises. The students have an opportunity to compare their logs with those developed by the consulting staff geologists.

As one might imagine, considerable interest outside of the Department was created by the flurry of activity and the sight of heavy equipment adjacent to the Science Building. Pictures and stories appeared in the campus newspaper, and students 


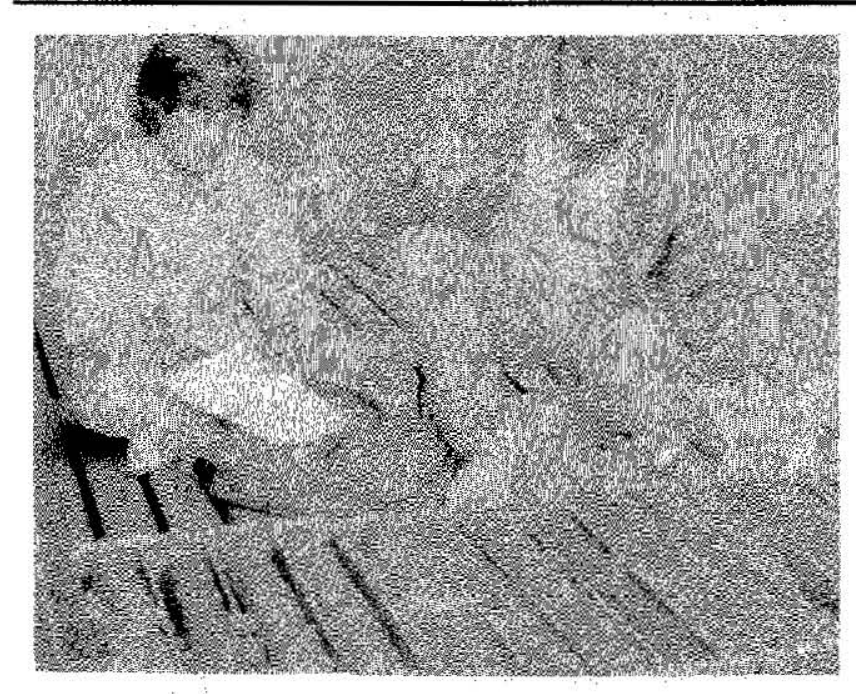

Figure 2. Staff geologist from EMCON explaining some of the finer points of logging recovered core from the wells to a Geology Department graduate student.

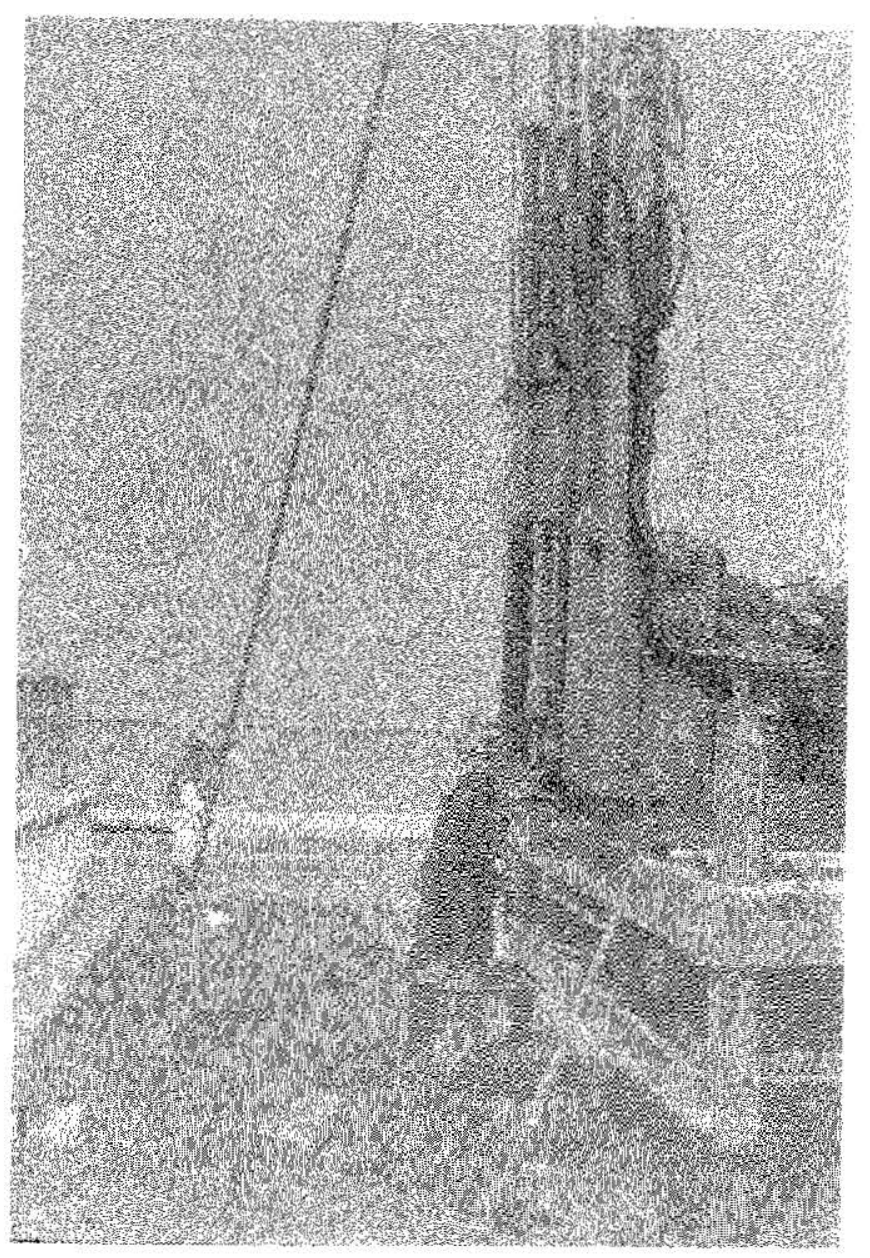

Figure 3. The drilling operations attracted and held the attention of geology students as well as other members of the San Jose State University academic community. (Photo by Greg Walton of the Spartan Dally Newspaper.)

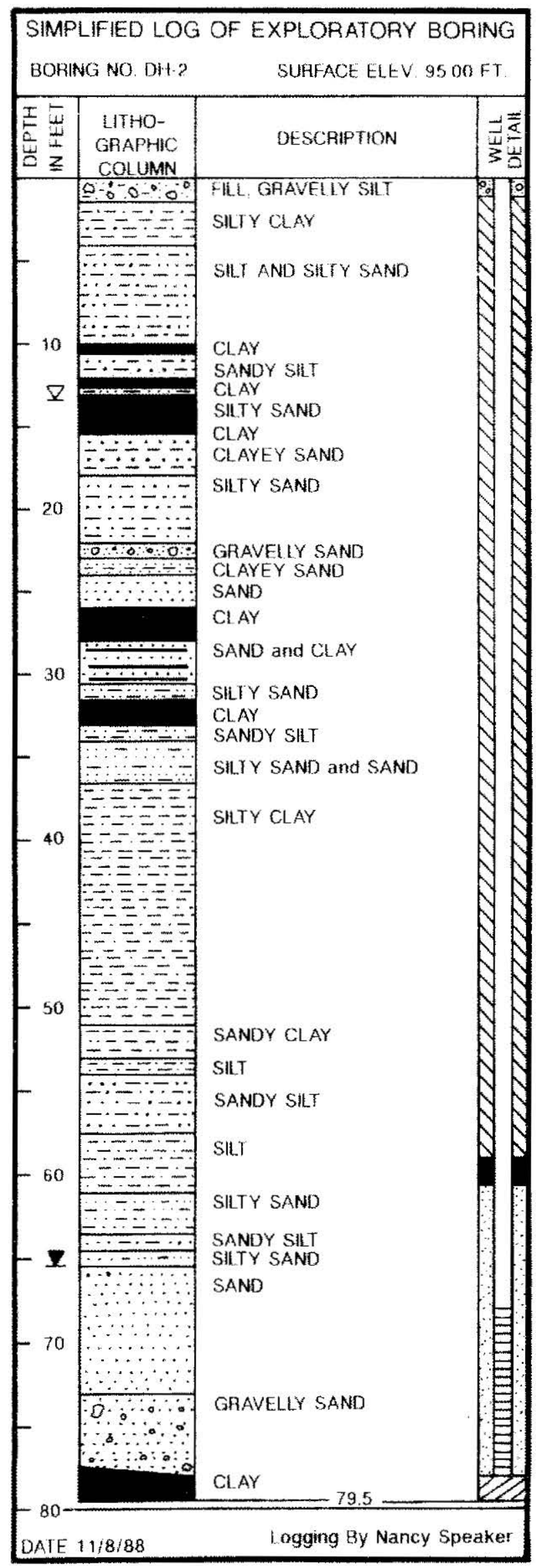


Figure 4 (lett). Simplifled well log and detall of well completion. Solld trlangle Indicates the stabilized water level. Open trlangle Indicates the level of water flrst encountered during drliling operations. Well screening interval Indicated by short horlzontal IInes between depths of 68 and 78 feet.

from other disciplines stopped to watch and ask questions about the project.

Comments from other geological consulting firms in the San Francisco Bay region have indicated that this opportunity for students to gain "hands-on" experience will greatly increase their chances for employment. These potertial employers indicate that applicants frequently have considerable theory but little application or field experience in their backgrounds. This educational opportunity is thought to be an important augmentation in the teaching of applied geology, particularly hydrogeology.

This project, funded in a somewhat unique fashion by lottery funds at a relatively modest cost, has produced a number of benefits including:

1) Provisions of a unique "hands-on" teaching tool that will be available for many years.

2) Provisions of opportunities to strengthen the working relationship between the university and the private consulting community. In this case the consulting firm saw the opportunity to work with the university and to help improve the educational facilities as a very desirable project of mutual benefit.

3) Creation of a permanent record (video tape) which can be used in various courses at various levels.

4) Appearance of newspaper articles, photographs, and onsite visits by students put applied geology in the public oye for a time.

\section{About the Author:}

June Ann Oberdorfer is an Associate Professor of Geology with a Pho trom the University of Hawall She teaches hydrogeology and has panticular interests in haz. ardous waste and computer modeling of ground water flow.

John Whanton Willams is a Professor of Geology and Chalr of the Department with a PhD from Stanford Univers sity. He teaches engineering goology and is interested in geologlo hazards incliding landstides and selsmically in. duced ground failures.

Mark Gordon Smelser is an Instructional Resources Technician in the Department of Geology with a BS in Geology from the Calfornia State Unversity, Sacramento. He uses his artistic ability to construct very effective goologic exhibits and illustrations.

\section{Food for Thought}

there is very litte evidence to support the claim that the right hemisphere fof the brainl s specialized for creativity This is otten taken as a given in popular discussions of asymmetry, but it is not based on any convincing ovidence. At best (and some conservative investigators would even argue this point), all we can say based on current evidence is that the right hemisphere is specialized for holistic, parallel processing. To extend this to creativity as a whole is a glant leap of faith that is as yet unsubstantiated by tact.

What about the notion of hemisphericity that holds that each person has a hatural pattern of hemispheric preference that makes some of us "left brained" or tight brained"? Here, too, we find little evidence 10 support such claims. Attempts to compare groups of individuals, such as creative artists and lawyers, on different measures of hemispheric symmety have not produced consistent findings We do not have any good data to support the idea of indvidual differences in patterns of hemispheric usage, nor do we have evidence that such patterns, f they did exist, could be modified by training.

Saly P Springer, 1989 , Educating the two stdes of the brain, separating fact from speculation: American Educator, $\vee, 13,10,1, \mathrm{p} 3237,52$ (from $\mathrm{P}, 37$ )

\section{Free Student Membership}

This form (when completed and attached to a paid application for a new, regular membership) entitles the student named below to a one-year free student membership in NAGT. A new regular member is someone who has been a regular member of NAGT for at least three years. Mail both forms to NAGT, Inc., Allen Press, P.O. Box 368, Lawrence, Kansas 66044.

Name

Address

City State Zip

Student status: Undergraduate Graduate

Certification of student status by departmental chair's signature 